\title{
Genome size differentiates co-occurring populations of the planktonic diatom Ditylum brightwellii (Bacillariophyta)
}

\author{
Julie A Koester ${ }^{1}$, Jarred E Swalwell ${ }^{1}$, Peter von Dassow ${ }^{2}$, E Virginia Armbrust ${ }^{1 *}$
}

\begin{abstract}
Background: Diatoms are one of the most species-rich groups of eukaryotic microbes known. Diatoms are also the only group of eukaryotic micro-algae with a diplontic life history, suggesting that the ancestral diatom switched to a life history dominated by a duplicated genome. A key mechanism of speciation among diatoms could be a propensity for additional stable genome duplications. Across eukaryotic taxa, genome size is directly correlated to cell size and inversely correlated to physiological rates. Differences in relative genome size, cell size, and acclimated growth rates were analyzed in isolates of the diatom Ditylum brightwellii. Ditylum brightwellii consists of two main populations with identical 18s rDNA sequences; one population is distributed globally at temperate latitudes and the second appears to be localized to the Pacific Northwest coast of the USA. These two populations co-occur within the Puget Sound estuary of WA, USA, although their peak abundances differ depending on local conditions.

Results: All isolates from the more regionally-localized population (population 2) possessed $1.94 \pm 0.74$ times the amount of DNA, grew more slowly, and were generally larger than isolates from the more globally distributed population (population 1). The ITS1 sequences, cell sizes, and genome sizes of isolates from New Zealand were the same as population 1 isolates from Puget Sound, but their growth rates were within the range of the slowergrowing population 2 isolates. Importantly, the observed genome size difference between isolates from the two populations was stable regardless of time in culture or the changes in cell size that accompany the diatom life history.

Conclusions: The observed two-fold difference in genome size between the D. brightwellii populations suggests that whole genome duplication occurred within cells of population 1 ultimately giving rise to population 2 cells. The apparent regional localization of population 2 is consistent with a recent divergence between the populations, which are likely cryptic species. Genome size variation is known to occur in other diatom genera; we hypothesize that genome duplication may be an active and important mechanism of genetic and physiological diversification and speciation in diatoms.
\end{abstract}

\section{Background}

Genotypic and physiological variation is frequently disguised by an apparent morphological constancy traditionally assumed to be stable enough for the assignment and identification of species. Cryptic species that display subtle variations in morphology associated with reproductive isolation have been described in all major phylogenetic lineages of eukaryotic marine phytoplankton

\footnotetext{
* Correspondence: armbrust@u.washington.edu

'School of Oceanography, Box 357940, University of Washington, Seattle WA
} 98195-7940, USA
[1-4], despite the fact that large population sizes and ocean mixing were expected to facilitate gene flow and homogenize species distinctions. Diatoms are the youngest [5] and the most species-rich group of phytoplankton $[6,7]$; they have risen quickly to become important contributors to oceanic ecosystems as primary producers and intermediates in the global biogeochemical cycles of carbon and silicon [8-10]. The mechanisms of speciation in diatoms remain under investigation.

Abrupt changes in an organism's genome size through polyploidy can lead to reproductive isolation and

\section{Biomed Central}


eventual speciation $[11,12]$. Diatoms are the only major group of eukaryotic phytoplankton with a diplontic life history, in which all vegetative cells are diploid and meiosis produces short-lived, haploid gametes, suggesting an ancestral selection for a life history dominated by a duplicated (diploid) genome. Polyploidization accounts for $2-4 \%$ of speciation events in flowering plants and up to $7 \%$ of speciation events in ferns [13]. In addition, stable polyploids were observed among laboratory populations of the diatom species Thalassiosira weissflogii (Grunow) Fryxell and Hasle [14]. Polyploidization may underlie the variation in chromosome number observed between and within diatom species [15-18].

A change in genome size precipitates a cascade of cellular responses leading to nearly universal relationships among genome size, cell size and metabolic rates $[19,20]$. In accord with other divergent taxa, genome size and cell size in phytoplankton are positively correlated [14,21-23]. Growth rates are inversely correlated with genome and cell sizes such that large-celled species with more DNA, including diatoms, grow more slowly than small-celled species with less DNA [24-26].

The relationship between cell size and genome size is of additional interest in diatoms. Asexual mitotic division produces two daughter cells, one of which is smaller than the mother cell due to the constraints of the rigid cell wall. Over time, the mean cell size of a clone decreases with each successive round of division, whereas the variance in size increases [27,28]. Large cell sizes are restored through sexual reproduction, or, less frequently, through asexual enlargement [29]. In a clonal lineage, the original sexual offspring can have 100-fold larger volumes than the smallest cells produced asexually. The smallest size that may be attained by a species is likely influenced by genome size, but the sizes of the largest cells are likely the result of genetic and environmental interactions during zygotic development.

High genetic divergence characterizes two co-occurring populations of the common coastal diatom Ditylum brightwellii (T. West) Grunow in van Heurk, which has a wide-spread coastal and estuarine distribution. In Puget Sound, WA, D. brightwellii is composed of two metapopulations that are defined by DNA sequence differences in the ribosomal internal transcribed spacers (ITS) $[30,31]$. Both metapopulations consist of two or more populations (defined by differences in microsatellite allele frequencies) that can co-occur in the water column [30-34]. For simplicity, the ITS-defined metapopulations will be referred to as populations throughout this study. Based on ITS sequencing of clones from the eastern and western margins of the Pacific and Atlantic Oceans including the Yellow Sea (Genbank: EU364892) and Gulf of Maine (pers. obs.), population 1 appears to have a circum-global distribution in temperate waters, while, to date, population 2 has been found only in Puget Sound [31]. By current taxonomic definitions, individuals from both populations are members of a single species: their $18 \mathrm{~s}$ rDNA gene sequences are identical, and there is no variation in the patterns of the silica cell wall, which are used traditionally to delineate species $[30,31,33]$. There are, however, differences between individuals from the two populations. Field isolates from population 1 are smaller than those from population 2 and the peaks of their blooms are temporally separated; this separation is differentially correlated to in situ silicic acid concentration and daily light exposure [30,31]. Even though both populations can be found in the water column at the same time, reproduction between them is limited, as evidenced by high $\mathrm{F}_{\mathrm{ST}}$ values (0.286) [30], which are consistent with the presence of cryptic species [35].

The observed differences in cell size and the limited gene flow between populations 1 and 2 of Ditylum brightwellii in the field led us to test the hypothesis that a difference in DNA content is associated with differences in acclimated growth rates and cell size separating the populations. Laboratory tests were performed within the context of two geographic scales, locally within Puget Sound, and globally, including D. brightwellii from New Zealand.

\section{Results}

Thirty-two isolates from Puget Sound, WA, USA and Akaroa Harbour, New Zealand (Fig. 1) were assigned to one of two Ditylum brightwellii populations based on the seven informative sites that distinguish the two ITS1 type-sequences [30]. The ITS1 sequences from all 10 New Zealand clones and 11 Puget Sound clones were identical to the type-sequence for population 1 (ITS1-1) from Puget Sound, including the seven informative sites, and were assigned to population 1. The ITS1 sequences for nine Puget Sound clones were identical to the ITS12 type sequence, including all of the informative sites, and were assigned to population 2. The ITS1 sequences for two Puget Sound clones were identical to the ITS1-2 type sequence at six of the seven informative sites. The ITS1 sequence of these two clones was polymorphic $(\mathrm{C} /$ $\mathrm{T}$ ) at the fourth informative site, which was previously determined to have low-frequency variation between $\mathrm{C}$ and $\mathrm{T}$ and is therefore informative only if sequence at the other positions is known [31]. These two clones were also assigned to population 2.

Growth rates varied among clones within each of the three groups (New Zealand and Puget Sound populations 1 and 2), but among-group differences in growth rates were greater (Fig. 2A-C). When clones were maintained on a light:dark cycle, the mean growth rate of clones from Puget Sound population $1\left(1.24 \pm 0.11 \mathrm{~d}^{-1}\right)$ 


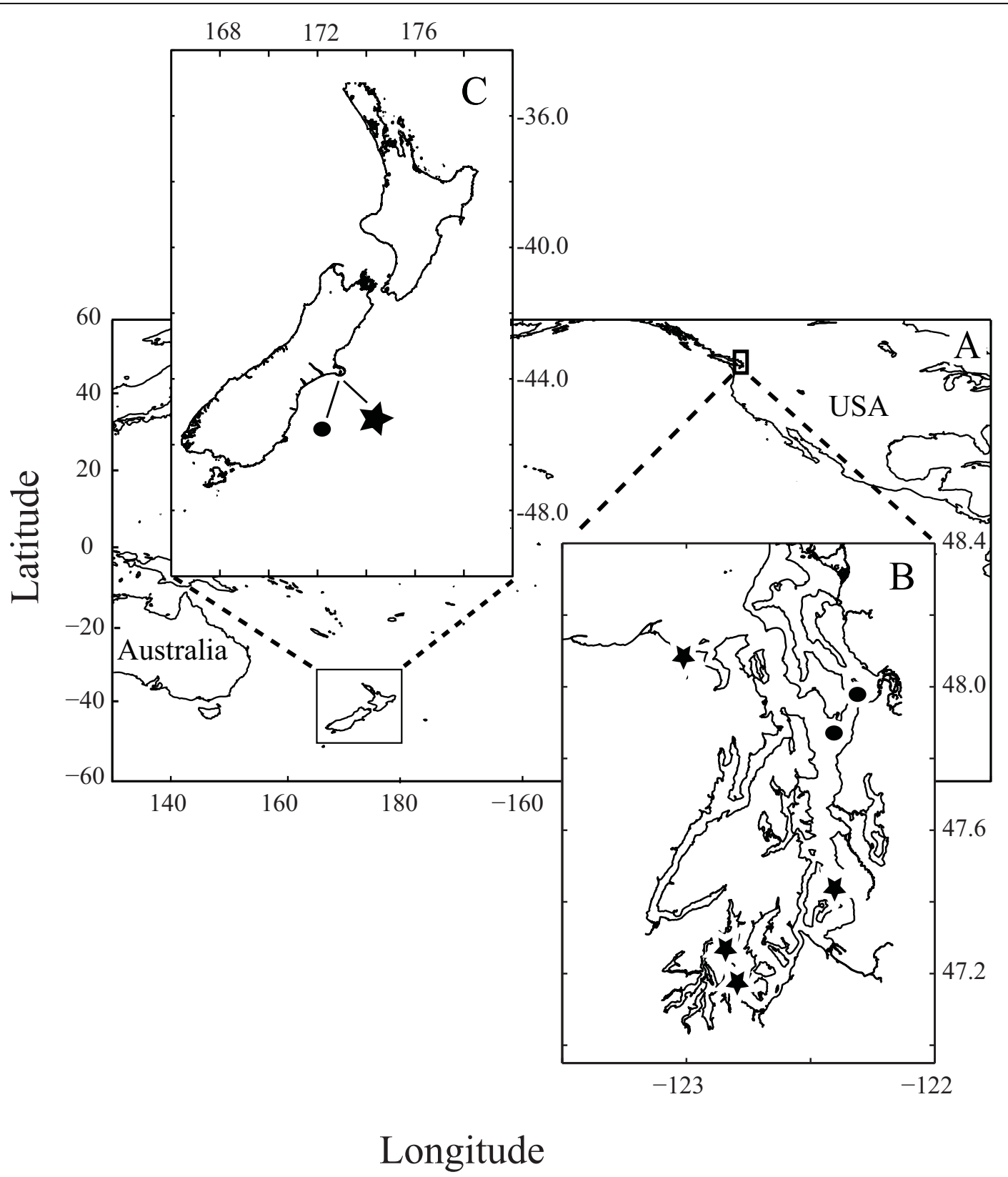

Figure 1 Sampling locations from which clones were isolated. A) Plan view of the Pacific Ocean with insets for: B) Puget Sound and C) New Zealand's Akaroa Harbour. Stars and circles represent sampling sites for clones isolated in 2006 and 2007, respectively.

was significantly faster than the mean growth rates of clones from either New Zealand $\left(1.09 \pm 0.04 \mathrm{~d}^{-1}\right)$ or Puget Sound population $2\left(0.99 \pm 0.13 \mathrm{~d}^{-1}\right)$ (ANOVA: F $=11.18, p=0.001$; Fig. 2A). Population 2 clones had the greatest range of growth rates, which included the slowest growing clones of either population, but the average growth rates of population 2 and New Zealand clones were not significantly different (Fig. 2A). Under conditions of continuous light, a majority of the population 2 clones failed to acclimate to the conditions within the eight week duration of each experiment (Fig. 2B, C). These un-acclimated clones grew, but no set of three consecutive transfer cultures grew at the same rate. In contrast, a majority of the population 1 clones were able to acclimate to growth under continuous light.

Cell widths were measured for clones included in the light:dark treatment of the growth rate experiments. Population 1 clones from New Zealand and Puget Sound had the same modal cell width of $14.6 \mu \mathrm{m}$ (Fig. 2D). Population 2 clones from Puget Sound had a modal cell 
width of $43.9 \mu \mathrm{m}$, and were significantly larger than population 1 clones (Mann-Whitney $U$ test; $U=29,672$; $p=0.000$ ), although individual clones from both populations did have overlapping size ranges (Fig. 2D).

The relative difference in DNA content between the populations of Ditylum brightwellii was determined using flow cytometry to measure the integrated SYBR GREEN I fluorescent signal of 12 clones from the growth rate experiments and 10 fresh isolates. The resulting distributions of DNA content were unimodal regardless of which clone was analyzed, suggesting that when grown exponentially on a 16:8 light:dark cycle all clones had progressed similarly through the cell cycle and were sampled while the majority of cells were in G1. The DNA distributions of single clones from population 1 and 2 were significantly different from each other (Fig 3; Mann-Whitney $\mathrm{U}$ test, $\mathrm{U}=3 \times 10^{7}, p=$ 0.000). To diminish the potential occurrence of multimodality around the peaks of the distributions, non-uniform quantization of the signal, rather than traditional histograms, was used for subsequent analyses. The nonquantized value is termed the mode. Both methods of analysis resulted in distributions centered on single values (the modes) interpreted as the diploid DNA content of G1 cells. There was no indication of a second mode representing G2+M cells (e.g. Fig. 3). The DNA content per cell was not significantly different among individual clones within a population; the mean integrated SYBR signals of population 1 clones were $2.72 \pm$ 0.78 and $3.11 \pm 0.50$, in relative units, for New Zealand and Puget Sound isolates, respectively. In contrast, the per cell DNA content of clones from population 2, 5.65 \pm 0.82 relative units, was significantly greater than that of clones from population 1 (Fig. 4A; ANOVA: $\mathrm{F}=$ $73.29, p=0.000)$. The ratio of the relative DNA content between populations 1 and 2 was $1.94 \pm 0.74$.

Clones associated with the DNA content experiments were isolated 18 months apart and cultured without controlling for size increases or decreases inherent in the diatom life history. Distributions of cell width were pooled for clones within each population, and the resulting two distributions were significantly different (Mann-Whitney $\mathrm{U}$ test, $\mathrm{U}=63,932, p=0.000$ ). Population 2 cells, which have a two-fold larger DNA content, tended to have greater minimum and maximum widths than cells from population 1 (Fig. 4B). A clear correlation between genome size and cell size is obscured by the overlap of cell width distributions of individual clones from each population (Fig. 4B). For example, clones 14-17 from Puget Sound population 1 and clones 18-20 from population 2 are of similar size, yet they have distinct genome sizes representative of their population of origin (Fig. 4A and 4B).

\section{Discussion}

Diatoms are a relatively young, but diverse, group of eukaryotic micro-organisms that arose approximately 250 million years ago [36]. The genomes of diatoms appear to be highly flexible and evolve rapidly with respect to their size and gene content, which allows for ecological differentiation [14,37-40]. Here we present evidence that genomic flexibility underlies the recent divergence of two closely related populations of Ditylum brightwellii, distinguished from each other by a two-fold difference in DNA content. This difference in genome size appears to be stable regardless of the amount of time isolates from the two populations have been maintained as laboratory cultures.

The DNA content of $D$. brightwellii was previously estimated to be $12.9 \mathrm{pg}$ per cell [21], which is the equivalent of 12.6 gigabases of DNA (assuming $980 \mathrm{MB}$ $\left.\mathrm{pg}^{-1} ;[41]\right)$ distributed amongst anywhere from 12-50 chromosomes in each diploid cell $[42,43]$. At least part of the explanation for the wide range in chromosome number is because karyotyping of diatoms is complicated by the presence of a rigid silica cell wall that prevents the consistent flattening of cells required to spread the condensed chromosomes apart for accurate enumeration [44]. We instead modified a flow cytometer to analyze thousands of the D. brightwellii cells that are up to $150 \mu \mathrm{m}$ in width to gain an accurate estimate of the range of relative genome sizes for cultured isolates from Puget Sound, WA and from New Zealand. All distributions of DNA content were unimodal with a skew (right hand tail) towards higher DNA content. Actively dividing cells appear to spend the greatest proportion of their cell cycle in phases G1, forming the peak (or mode) of the distribution, and S, represented by cells under the tail. Thalassiosira weissflogii, a diatom with a six to twelve-fold smaller genome relative to $D$. brightwellii (Koester et al. unpublished data), spends a third of its cell cycle in $\mathrm{S}$ phase when maintained in continuous light and otherwise optimal growth conditions [45], suggesting that the $\mathrm{S}$ phase of the much larger genome of $D$. brightwellii represents an even greater proportion of the cell cycle. The level of experimental replication and consistency of the time of day that the cultures were collected and preserved argues strongly that cell cycle dynamics were comparable for clones of both populations, with few cells residing in the $\mathrm{G} 2+\mathrm{M}$ phase.

The most parsimonious explanation for the observed two-fold difference in DNA content between the two populations of $D$. brightwellii is a whole genome duplication event occurring within cells of population 1 creating a polyploid lineage that ultimately gave rise to population 2 cells. Mitotic and meiotic failures are potentially important and immediate mechanisms 


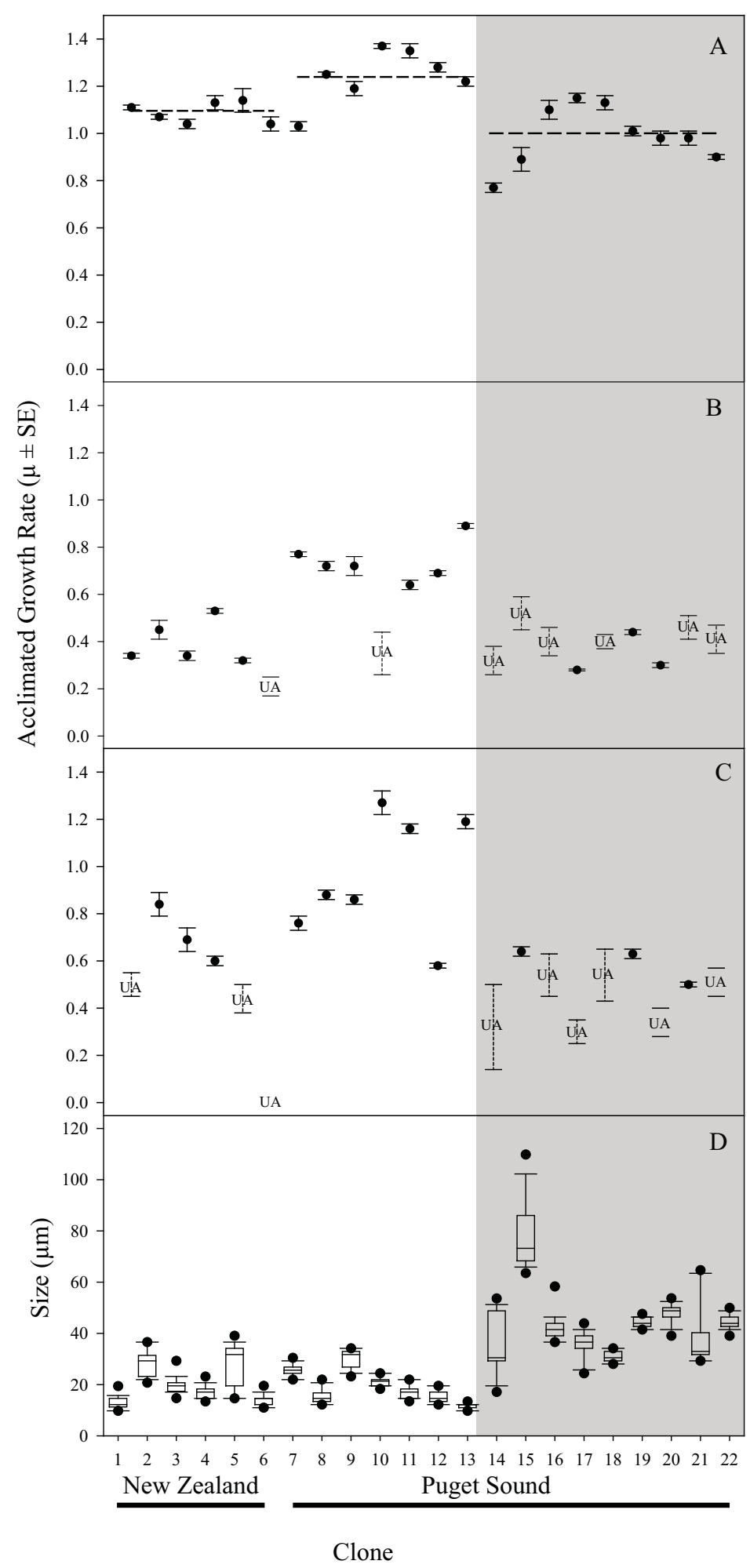

Figure 2 Acclimated growth rates (A -C) and size distributions (D) of Ditylum brightwellii. Growth conditions: A) $110 \mu \mathrm{mol}$ photons $\mathrm{m}^{-2} \mathrm{~s}^{-1}$; 16:8 L:D; B) $115 \mu \mathrm{mol}$ photons $\mathrm{m}^{-2} \mathrm{~s}^{-1}$; 24 hour light; C) $60 \mu \mathrm{mol}$ photons $\mathrm{m}^{-2} \mathrm{~s}^{-1} ; 24$ hour light. For acclimated clones, the mean growth rate \pm standard error is provided. UA denotes clones unable to acclimate and the associated error bars indicate the range in growth rates. D) Boxplot parameters for the distributions of cell width $(\mu \mathrm{m})$ : bar $=$ median; box $=1^{\text {st }}$ and $3^{\text {rd }}$ quartiles; whiskers $=10^{\text {th }}$ and $90^{\text {th }}$ percentiles; filled circles $=$ outliers. $N=120$ cells per clone. In all panels, white regions represent population 1 clones and grey regions represent population 2 clones. 


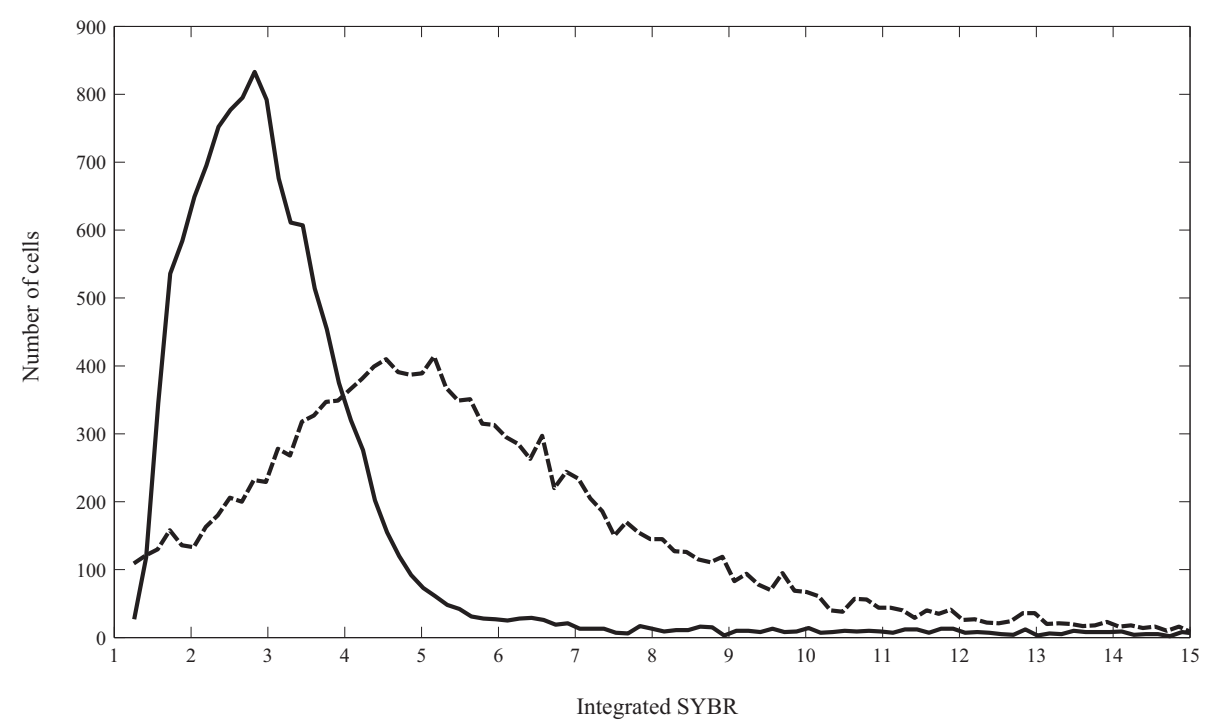

Figure 3 Linearly calibrated integrated SYBR signals of two clones of Ditylum brightwellii. Population 1 (solid line) and population 2 (dashed line) are represented by histograms each consisting of 200 bins of equal size.

contributing to DNA content differences among diatom lineages, assuming that cells survive the initial mutation and are able to propagate asexually. Triploid and tetraploid zygotes have been observed in five genera of pennate diatoms [46-50], and non-disjunction of spermatocytes during meiosis was observed in the same species as stable polyploids [14]. Alternatively, genome size may increase via aneuploidy, gene duplication, or the rapid proliferation of transposable elements. Transposable elements were previously proposed as a primary mechanism of genome size expansion in diatoms [39] because there was no evidence of whole genome or segmental duplications in either of the two diatoms with completed genome sequences, yet both contained longterminal-repeat retrotransposons [39,51].

The relationship between genome size and cell size spans five orders of magnitude for both factors and is a nearly universal trend in eukaryotes [20]. Diatoms, however, are unique in that cell-wall structure causes size reduction during asexual reproduction and different cells within a clone may have vastly different sizes; therefore, a clear correlation between cell size and genome size among closely related species with genomes of similar size is unlikely to be found. Nevertheless, there are indications that genome size influences the minimum size of Ditylum brightwellii clones. The appearance of large cells in clones dominated by small sizes suggests that the majority of population 1 was within the sexually inducible size range for $D$. brightwellii [52], and that minimum cell sizes were likely being approached by all of the clones isolated in 2006 and maintained in culture for 18 months. It is notable that the smallest cell sizes found in clones of population 2, which has the larger DNA content, tended to be larger than the smallest cell sizes found in clones from population 1. Most importantly, with regard to genome size and cell size, the diploid genome size is consistent among clones within a population, regardless of the variation in cell size caused by life history constraints.

Similar to traditional common garden experiments, our growth rate experiments tested for genetic differences among clones of Ditylum brightwellii from two populations, differentiated by genome size, and two groups of clones from population 1 represented by different geographic origins. The differences in growth rates between groups, populations 1 and 2 and New Zealand versus Puget Sound population 1 isolates, were greater than any within group variability. Growth rate variability may occur at the extremes of cell size within a clone $[53,54]$, but those effects would be masked in our study by cell size variability within each clone and diminished by the large difference in growth rates between the groups. Population 2 clones grew more slowly than population 1 clones from the same region, consistent with the expectation that cells with larger cell sizes and larger genomes will have slower growth rates. However, population 1 clones from New Zealand grew more slowly than population 1 clones from Puget Sound, suggesting that other genetic factors are also responsible for setting rates of growth. New Zealand clones are likely adapted to oceanic conditions that are distinct from the estuarine waters of Puget Sound.

Rapid selection for cell and/or genome size among diatoms is indicated in the fossil record and appears to 


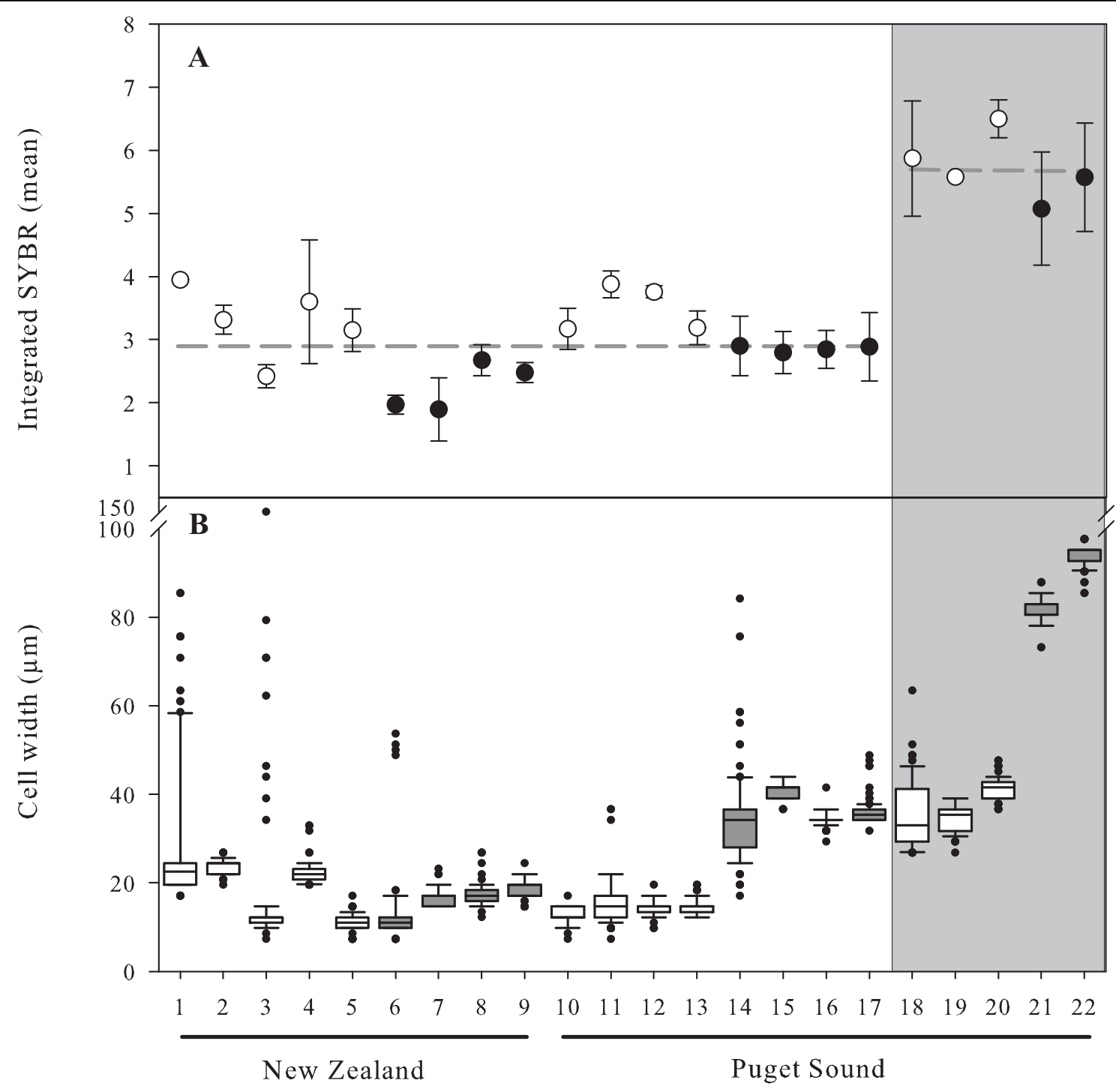

Clone

Figure 4 Relative genome sizes (A) and cell size distributions (B) of Ditylum brightwellii from two populations. A) The mean mode of the linearly calibrated integrated SYBR signal is given for clones collected in 2006 (white circles) where the whiskers represent the actual values of each duplicate, and clones collected in 2007 (black circles) where the whiskers represent the standard deviation of the triplicate samples. B) Size distributions of the cell width $(\mu \mathrm{m})$ in each clone at the time of the flow cytometry measurements. $N=100$ cells per clone. Boxplot parameters: bar $=$ median; box $=1^{\text {st }}$ and $3^{\text {rd }}$ quartiles; whiskers $=10^{\text {th }}$ and $90^{\text {th }}$ percentiles; filled circles = outliers. White boxes represent 2006 clones and grey boxes represent 2007 clones. White panel-regions represent population 1 clones and grey panel-regions represent population 2 clones.

be associated with climate variability [55]. Large cells (> $100 \mu \mathrm{m}$ diameter) of the morpho-species Azpeitia nodulifera (A. Schmidt) Fryxell and Sims (previously described as Coscinodiscus nodulifer Schmidt) intermittently enter and exit the sedimentary record, normally dominated by cells $40 \mu \mathrm{m}$ in diameter, over the course of thousands of years [56,57]. The lack of variability in morphology and the 18S rDNA gene between the two populations of Ditylum brightwellii suggests that the genome duplication event was recent and rapid. Genomic plasticity has likely contributed to speciation among diatoms and may be an important factor in the adaptation of diatoms to future ocean conditions.

\section{Conclusions}

The majority of phytoplankton have haplontic life histories [58]; therefore, a transition to a stable duplicated genome and a diplontic life history are likely at the root 
of the diatoms, the only phytoplankton group whose membership is diplontic. The propensity for further duplications may be a key mechanism of speciation among diatoms. Speciation is best identified by using a suite of divergent traits including reproductive isolation, morphology, ecological and physiological differences facilitated by genetic divergence. A high $\mathrm{F}_{\mathrm{ST}}$ value between the two populations of Ditylum brightwellii already indicated that that the process of reproductive isolation was underway, and that these two populations could represent separate species [30]. Duplicated genes, arising from the hypothesized whole genome duplication between the populations, may be released from selective pressures allowing for mutations that may be masked until environmental regimes change and they provide an adaptive advantage to the cell [59]. The apparent localization of population 2 to Pacific Northwest waters appears to reflect a recent divergence of the populations initiated by a whole genome duplication event. Population 1 and 2 most likely represent cryptic species in which interbreeding is greatly reduced and phenotypic differentiation is enhanced. In conjunction with previous work on genome size variation in diatoms, these results suggest that polyploidization is an active mechanism contributing to the diversification and speciation of marine diatoms.

\section{Methods}

\section{Cell isolation and culturing}

Single cells of Ditylum brightwellii were isolated from Puget Sound, Washington, USA and from the mouth of Akaroa Harbour, New Zealand during the spring and summers of 2006 and 2007 (Fig. 1). Thirty-two clonal, non-axenic cell lines were obtained by micropipetting individual cells through three aliquots of sterilized seawater into $0.5 \mathrm{ml} \mathrm{f} / 10$ medium [60] in a 48-well plate (Costar, Corning, NY). After one week, each clone was transferred to $25 \mathrm{ml} \mathrm{f} / 2$ medium and maintained as stock cultures at $13^{\circ} \mathrm{C}$, with an irradiance of approximately $40 \mu \mathrm{mol}$ photons $\mathrm{m}^{-2} \mathrm{~s}^{-1}$ and a photoperiod of 16:8 h light:dark.

\section{DNA sequencing}

Fifty to $100 \mathrm{ml}$ of clonal culture were filtered onto 25 $\mathrm{mm}, 5 \mu \mathrm{m}$ pore size, polycarbonate membrane filters (Millipore) for DNA extraction using either the DNeasy Plant Mini Kit (Qiagen) or the Easy-DNA Kit (Invitrogen), following manufacturer instructions. The internal transcribed spacer sequence 1 (ITS1) was polymerase chain reaction (PCR)-amplified with primers $1645 \mathrm{~F}$ and Dit5.8sR as described in [30]. Products from six amplification reactions were pooled and purified in one of two ways. The pooled PCR product was either directly purified using the High Pure PCR Product Purification Kit (Roche Applied Science) or electrophoresed in 1\% agarose gels and bands of the appropriate size were excised and extracted from the agarose with the QIAquick Gel Extraction Kit (Qiagen). The resulting fragments were sequenced using primers $1645 \mathrm{~F}$ and Dit5.8sR with the DYEnamic ET Terminator Cycle Sequencing Kit (GE Healthcare Bio-sciences Corp., New Jersey) and analyzed on a MegaBACE 1000 automated sequencer (GE Healthcare Biosciences Corp., New Jersey). Sequences were assigned to a population by aligning them to two type-sequences [Genbank: DQ329268] (population 1; ITS1-1) and [Genbank: DQ329270] (population 2; ITS12 ). Genbank accession numbers for ITS1 sequences from our study are [Genbank: GQ370472-GQ370503].

\section{Growth rate and size}

Acclimated growth rates were determined using semicontinuous batch cultures [61] of the clones isolated in 2006 plus one clone from population 1 isolated in 1997 and one from population 2 isolated in 1998 from Puget Sound by $[32,33]$. The ITS1 sequences of the latter two clones were confirmed in this study. In total, six isolates from New Zealand, seven from Puget Sound population 1 , and nine from Puget Sound population 2 were grown at $13^{\circ} \mathrm{C}$ under three different light conditions: continuous light of 60 and $115 \mu \mathrm{mol}$ photons $\mathrm{m}^{-2} \mathrm{~s}^{-1}$, and a $16: 8 \mathrm{~h}$ light:dark cycle of $110 \mu \mathrm{mol}$ photons $\mathrm{m}^{-2} \mathrm{~s}^{-1}$. The 60 $\mu \mathrm{mol}$ photons $\mathrm{m}^{-2} \mathrm{~s}^{-1}$ continuous light experiment was completed prior to the other two, which were run simultaneously in separate incubators. Growth rates were determined by measuring chlorophyll $a$ fluorescence daily with a Turner 10-AU Fluorometer (Sunnyvale, CA) and verified for a subset of clones by performing daily cell counts (data not shown). Acclimated growth rates of each clone were defined as the specific growth rates of cultures that were not significantly different over three consecutive transfers (ANCOVA; [62]); the common slope and associated standard error are reported as the acclimated growth rate.

Cell size was measured at two discrete times, once at the conclusion of the growth rate experiments (from the light:dark treatment) and once in conjunction with the DNA content experiments. Cells were preserved in a $1 \%$ final concentration each of formaldehyde and glutaraldehyde buffered with sterile $f / 2$ medium. Cell width is the dimension of size reduction in Ditylum brightwellii; therefore, widths were measured in girdle view, perpendicular to the pervalvar (long) axis at the widest point, at 400× magnification using a Nikon Eclipse TS100 inverted microscope equipped with an ocular micrometer. Differences in size and growth rates among populations were analyzed using the statistics package SPSS (SPSS, Inc., Chicago, IL).

\section{Relative genome size}

Relative DNA content (diploid genome size) was measured using flow cytometry for 12 clones isolated in 2006 and maintained in culture for 18 months and 10 
clones isolated in 2007 approximately six months and six weeks, respectively, prior to measurement. One hundred $\mathrm{ml}$ of each clone were grown in a 16:8 h light: dark cycle with $110 \mu \mathrm{mol}$ photons $\mathrm{m}^{-2} \mathrm{~s}^{-1}$ at $13^{\circ} \mathrm{C}$. Clones were harvested in mid-exponential phase, half way through the light cycle, and concentrated by centrifugation $(15 \mathrm{~min}$ at $1700-2000 \times \mathrm{g})$. The pellet was suspended in $15 \mathrm{ml}$ of $100 \%$ methanol at $4^{\circ} \mathrm{C}$ for $48 \mathrm{~h}$ to extract chlorophyll $a$ [45]. Samples were centrifuged and washed twice with $4 \mathrm{ml}$ phosphate buffered saline (PBS; $137 \mathrm{mM} \mathrm{NaCl}, 2.7 \mathrm{mM} \mathrm{KCl}, 10.4 \mathrm{mM} \mathrm{Na}_{2} \mathrm{H}$ $\mathrm{PO}_{4} \cdot \mathrm{H}_{2} \mathrm{O}, 1.8 \mathrm{mM} \mathrm{KH} \mathrm{PO}_{4}, \mathrm{pH}=7.4$ ) before being resuspended in $3 \mathrm{ml}$ PBS and treated with $30 \mu \mathrm{l}$ RNase A (ca. $30 \mathrm{mg} \mathrm{ml}^{-1}$; R4642; Sigma-Aldrich, St. Louis, $\mathrm{MO})$ at $37^{\circ} \mathrm{C}$ for $60 \mathrm{~min}$. The DNA was stained with SYBR GREEN I (Invitrogen), at $1 \times$ final concentration, for at least $20 \mathrm{~min}$. Fluorescent, $1 \mu \mathrm{m}$ latex beads (Polysciences, Warrington, PA) were added as standards to each sample. Stained samples were kept on ice in the dark until run on the flow cytometer. Each clone of a sampling set (2006 or 2007) was analyzed on a given day, and replicate clonal samples were analyzed on separate days. Clones were grown and processed independently for replicate measurements; duplicate and triplicate measurements of relative genome size were made for 2006 and 2007 isolates, respectively. Mean sample sizes ranged from 8400 - 24,000 cells per clone per replicate.

An Influx Cell Sorter (BD Biosciences, San Jose, CA) was modified to include a $500 \mu \mathrm{m}$ sample line, and a $200 \mu \mathrm{m}$ nozzle producing a sample stream intercepting a $300 \mathrm{~mW}, 457 \mathrm{~nm}$ laser focused to $20 \mu \mathrm{m}$. A $10 \times$ objective lens and position sensitive detectors [63] allowed for the detection of the SYBR signal $(530 / 20 \mathrm{~nm}$ bandpass filter), which was processed through an electronic integrator that produced a 16-bit data value (BD Biosciences, San Jose, CA).

Integrated SYBR signals for each cell of a single clone were usually unique; therefore, a central tendency, henceforth referred to as the mode, of the integrated SYBR signal was determined for each clone using a custom MATLAB script (MathWorks, Natick, MA). Non-uniform quantization was performed on the integrated SYBR signal for each replicate sample such that bins were variable in width. The number of cells in each bin was constant $\left(160\right.$ cells bin $\left.{ }^{-1}\right)$ and optimized by choosing a cell number that minimized the mean square error of the integrated SYBR values within each bin and the number of equally narrow bins. The mean value of the integrated SYBR signal from the narrowest bin, which represented the greatest concentration of cells within the smallest range of integrated SYBR signals, was taken as the mode. In the minority of cases in which two nearby bins were equally narrow, the mean of the range of the two bins was calculated as the mode. Bimodality would be indicated by equally narrow bins occurring at a distance apart.

The integrator was calibrated for linearity by collecting the integrated fluorescent signals of beads $(1 \mu \mathrm{m})$ and their doublets as the gain was increased by $2 \times$ intervals across the dynamic range of the integrator. The relationship between the linear input values of the beads and their integrated SYBR signal was determined to be of the form $f(x)=A^{b x}$, where $f(x)=$ linear value, $A=$ $0.6445, \mathrm{~b}=5.99 \times 10^{-5}$, and $\mathrm{x}=$ integrated SYBR signal yielded the best fit $\left(\mathrm{SSE}=1.397 ; \mathrm{R}^{2}=0.9972\right.$; CurveFit Toolbox, MATLAB). Modal values of the integrated SYBR signal were applied to this equation with the linear output reported here.

\section{Acknowledgements}

We would like to thank Mark Webber and Raphael Hoekstra for New Zealand samples, Karie Holtermann for selected Puget Sound samples and Tatiana Rynearson for two early clonal isolates. We also thank Rachelle Lambert for laboratory assistance and Ger van den Engh and Timothy Petersen for consultation on flow cytometry. A special thanks to Vaughn Iverson for discussions on signal processing and to Kate Hubbard, Colleen Durkin and Adrian Marchetti for insightful discussions throughout the research. This research was funded by the Gordon and Betty Moore Foundation Marine Microbiology Investigator Award to E.V.A. PvD was supported by a Marie Curie International Incoming Post-doctoral Fellowship (European Commission) and an NSF Microbiology Post-doctoral Fellowship.

\section{Author details}

${ }^{1}$ School of Oceanography, Box 357940, University of Washington, Seattle WA 98195-7940, USA. ${ }^{2}$ CNRS, UMR7144, Evolution du Plancton et PaleoOceans, Station Biologique de Roscoff, BP 74, Roscoff 29682, France.

\section{Authors' contributions}

JAK participated in and implemented all levels of this study including experimental design, statistical analysis and drafting of the manuscript. JS executed the design, development and operation of the flow cytometer. PVD participated in preliminary experiments, final experimental design and drafting of the manuscript. EVA participated in experimental design and drafting of the manuscript. All authors have read and approve of the final manuscript.

Received: 5 August 2009

Accepted: 2 January 2010 Published: 2 January 2010

\section{References}

1. Medlin LK, Elwood HJ, Stickel S, Sogin ML: Morphological and genetic variation within the diatom Skeletonema costatum (Bacillariophyta): Evidence for a new species, Skeletonema pseudocostatum. J Phycol 1991, 27:514-524.

2. Montresor M, Sgrosso S, Procaccini G, Kooistra WHCF: Intraspecific diversity in Scrippsiella trochoidea (Dinophyceae): evidence for cryptic species. Phycologia 2003, 42(1):56-70.

3. Sáez AG, Probert I, Geisen M, Quinn P, Young JR, Medlin LK: Pseudo-cryptic speciation in coccolithophores. Proc Natl Acad Sci USA 2003, 100(12):71637168.

4. Rodríguez F, Derelle E, Guillou L, Le Gall F, Vaulot D, Moreau H: Ecotype diversity in the marine picoeukaryote Ostreococcus (Chlorophyta, Prasinophyceae). Environ Microbiol 2005, 7(6):853-859.

5. Falkowski PG, Katz ME, Knoll AH, Quigg A, Raven JA, Schofield O, Taylor FJR: The evolution of modern eukaryotic phytoplankton. Science 2004, 305:354-360.

6. Mann DG, Droop SJM: Biodiversity, biogeography and conservation of diatoms. Hydrobiologia 1996, 336(1-3):19-32. 
7. Kooistra WHCF, Gersonde R, Medlin LK, Mann DG: The origin and evolution of the diatoms: Their adaptation to a planktonic existence. Evolution of primary producers in the sea Amsterdam, Boston: Elsevier Academic PressFalkowski PG, Knoll AH 2007, 210-250.

8. Harrison KG: Role of increased marine silica input on paleo- $p \mathrm{CO}_{2}$ levels, Paleoceanography 2000, 15(3):292-298

9. Nelson DM, Tréguer P, Brzezinski MA, Leynaert A, Quéguiner B: Production and dissolution of biogenic silica in the ocean: Revised global estimates, comparison with regional data and relationship to biogenic sedimentation. Global Biogeochem Cycles 1995, 9(3):359-372.

10. Tréguer P, Pondaven P: Silica control of carbon dioxide. Nature 2000, 406:358-359.

11. Husband BC, Sabara HA: Reproductive isolation between autotetraploids and their diploid progenitors in fireweed, Chamerion angustifolium (Onagraceae). New Phytol 2003, 161(3):703-713.

12. Soltis DE, Soltis PS, Schemske DW, Hancock JF, Thompson JN, Husband BC, Judd WS: Autopolyploidy in angiosperms: have we grossly underestimated the number of species?. Taxon 2007, 56(1):13-30,

13. Otto SP, Whitton J: Polyploid incidence and evolution. Annu Rev Genet 2000, 34:401-437.

14. von Dassow P, Petersen TW, Chepurnov VA, Armbrust EV: Inter- and intraspecific relationships between nuclear DNA content and cell size in selected members of the centric diatom genus Thalassiosira (Bacillariophyceae). J Phycol 2008, 44(2):335-349.

15. Kociolek JP, Stoermer EF: Chromosome numbers in diatoms: A review. Diatom Res 1989, 4:47-54

16. Giri BS, Chowdary YBK, Sarma YSRK: Cytological studies on some pennate diatoms. The Nucleus 1990, 33(3):141-144.

17. Giri BS: Karyology of the genus Cyclotella Kütz (Bacillariophyceae). Cytologia 1991, 56:494-494.

18. Giri BS: Nuclear cytology of naviculoid diatoms. Cytologia 1992, 57:173179.

19. Gregory TR: Coincidence, coevolution, or causation? DNA content, cell size, and the C-value enigma. Biological Reviews 2001, 76(1):65-101.

20. Cavalier-Smith T: Economy, speed and size matter: Evolutionary forces driving nuclear genome miniturization and expansion. Ann Bot 2005, 95:147-175.

21. Holm-Hansen O: Algae: amounts of DNA and organic carbon in single cells. Science 1969, 163:87-88

22. Veldhuis MJW, Cucci TL, Sieracki ME: Cellular DNA content of marine phytoplankton using two new fluorochromes: Taxonomic and ecological implications. J Phycol 1997, 33(3):527-541

23. Beaton MJ, Cavalier-Smith T: Eukaryotic non-coding DNA is functional: evidence from the differential scaling of cryptomonad genomes. Proc $R$ Soc Lond B Biol Sci 1999, 266(1433):2053-2059.

24. Williams RB: Division rates of salt marsh diatoms in relation to salinity and cell size. Ecology 1964, 45(4):877-880.

25. Shuter BJ, Thomas JE, Taylor WD, Zimmerman AM: Phenotypic correlates of genomic DNA content in unicellular eukaryotes and other cells. Am Nat 1983, 122:26-44

26. Chisholm SW: Phytoplankton size. Primary Productivity and biogeochemical cycles in the sea: Environmental science research New York: Plenum PressFalkowski PG, Woodhead AD 1992, 43:213-237.

27. MacDonald JD: On the structure of the diatomaceous frustule, and its genetic cycle. Mag Nat Hist 1869, 4(13):1-8.

28. Pfitzer E: Untersuchungen über Bau und Entwickelung der Bacillariaceen (Diatomaceen). Bot Abhandl (ed Hanstein) 1871, 1(2):1-189.

29. Chepurnov VA, Mann DG, Sabbe K, Vyverman W: Experimental studies on sexual reproduction in diatoms. Int Rev Cytol 2004, 237:91-154.

30. Rynearson TA, Newton JA, Armbrust EV: Spring bloom development, genetic variation, and population succession in the planktonic diatom Ditylum brightwellii. Limnol Oceanogr 2006, 51(3):1249-1261.

31. Rynearson TA, Lin EO, Armbrust EV: Metapopulation structure in the planktonic diatom Ditylum brightwellii (Bacillariophyceae). Protist 2009, 160(1):111-121.

32. Rynearson TA, Armbrust EV: DNA fingerprinting reveals extensive genetic diversity in a field population of the centric diatom Ditylum brightwellii. Limnol Oceanogr 2000, 45(6):1329-1340.

33. Rynearson TA, Armbrust EV: Genetic differentiation among populations of the planktonic marine diatom Ditylum brightwellii (Bacillariophyceae). J
Phycol 2004, 40(1):34-43http://www3.interscience.wiley.com/journal/ 118757969/abstract.

34. Rynearson TA, Armbrust EV: Maintenance of clonal diversity during a spring bloom of the centric diatom Ditylum brightwellii. Mol Ecol 2005, 14:1631-1640.

35. Caputi L, Andreakis N, Mastrototaro F, Cirino P, Vassillo M, Sordino P: Cryptic speciation in a model invertebrate chordate. Proc Natl Acad Sci USA 2007, 104(22):9364-9369.

36. Sorhannus U: A nuclear-encoded small-subunit ribosomal RNA timescale for diatom evolution. Mar Micropaleontol 2007, 65(1-2):1-12.

37. Créach V, Ernst A, Sabbe K, Vanelslander B, Vyverman W, Stal LJ: Using quantitative $P C R$ to determine the distribution of a semicryptic benthic diatom, Navicula phyllepta (Bacillariophyceae). J Phycol 2006, 42(5):11421154

38. Oliver MJ, Petrov D, Ackerly D, Falkowski P, Schofield OM: The mode and tempo of genome size evolution in eukaryotes. Genome Res 2007, 17:594601

39. Bowler $\mathrm{C}$, Allen AE, Badger JH, Grimwood J, Jabbari K, Kuo A, Maheswari U, Martens C, Maumus F, Otillar RP, et al: The Phaeodactylum genome reveals the evolutionary history of diatom genomes. Nature 2008, 456(7219):239244

40. Armbrust EV: The life of diatoms in the world's oceans. Nature 2009, 459(7244):185-192.

41. Cavalier-Smith T: The Evolution of genome size. Chichester [West Sussex], New York: J. Wiley 1985

42. Gross F: The life history of some marine plankton diatoms. Philos Trans $R$ Soc Lond B Biol Sci 1937, 228:1-47.

43. Eppley RW, Holmes RW, Paasche E: Periodicity in cell division and physiological behavior of Ditylum brightwellii, a marine planktonic diatom, during growth in light-dark cycles. Arch Mikrobiol 1967, 56:305323.

44. Sarma YSRK: Algal karyology and evolutionary trends. Chromosomes in evolution of eukaryotic groups Boca Raton, Florida: CRC PressSharma AK, Sharma A 1983, I:177-224.

45. Vaulot D, Olson RJ, Chisholm SW: Light and dark control of the cell cycle in two marine phytoplankton species. Exp Cell Res 1986, 167:38-52

46. Mann DG, Stickle AJ: The genus Craticula. Diatom Res 1991, 6(1):79-107.

47. Mann DG: Auxospore formation, reproductive plasticity and cell structure in Navicula ulvacea and the resurrection of the genus Dickieia (Bacillariophyta). Eur J Phycol 1994, 29(3):141-157.

48. Chepurnov VA, Roshchin AM: Inbreeding influence on sexual reproduction of Achnanthes longipes Ag. (Bacillariophyta). Diatom Res 1995, 10:21-25

49. Chepurnov VA, Mann DG: Auxosporulation of Licmophora communis (Bacillariophyta) and a review of mating systems and sexual reproduction in araphid pennate diatoms. Phycol Res 2004, 52(1):112http://www3.interscience.wiley.com/journal/118803078/abstract.

50. Chepurnov VA, Mann DG, Vyverman W, Sabbe K, Danielidis DB: Sexual reproduction, mating system, and protoplast dynamics of Seminavis (Bacillariophyceae). J Phycol 2002, 38(5):1004-1019.

51. Armbrust EV, Berges JA, Bowler C, Green BR, Martinez D, Putnam NH, Zhou $S$, Allen $A E$, Apt KE, Bechner $M$, et al: The genome of the diatom Thalassiosira pseudonana: ecology, evolution, and metabolism. Science 2004, 306(5693):79-86.

52. Koester JA, Brawley SH, Karp-Boss L, Mann DG: Sexual reproduction in the marine centric diatom Ditylum brightwellii (Bacillariophyta). Eur J Phycol 2007, 42(4):351-366.

53. Paasche $E$ : The influence of cell size on growth rate, silica content and some other properties of four marine diatoms species. Norwegian Journal of Botany 1973, 20:197-204.

54. Amato A, Orsini L, D'Alelio D, Montresor M: Life cycle, size reduction patterns, and ultrastructure of the pennate planktonic diatom Pseudonitzschia delicatissima (Bacillariophyceae). J Phycol 2005, 41(3):542-556.

55. Finkel ZV, Katz ME, Wright JD, Schofield OME, Falkowski PG: Climatically driven macroevolutionary patterns in the size of marine diatoms over the Cenozoic. Proceedings of the National Acadamy of Sciences 2005, 102(25):8927-8932.

56. Arrhenius G: Sediment cores of the East Pacific. Reports of the Swedish Deep Sea Expeditions 1947-1948 1952 Stockholm: Swedish Natural Science Research Council 1952, 1-91. 
57. Burckle LH, McLaughlin RB: Size changes in the marine diatom Coscinodiscus nodulifer A. Schmidt in the equatorial Pacific. Micropaleontology (New York) 1977, 23(2):216-222.

58. Graham LE, Wilcox LW: Algae. Upper Saddler River, NJ: Prentice Hall 2000

59. Ohno S, (ed): Evolution by Gene Duplication. Berlin, New York: SpringerVerlag 1970.

60. Guillard RRL, Ryther JH: Studies of marine planktonic diatoms. I. Cyclotella nana Hustedt, and Detonula confervacea (Cleve) Gran. Can J Microbiol 1962, 8:229-239.

61. Brand LE, Guillard RRL, Murphy LS: A method for the rapid and precise determination of acclimated phytoplankton reproduction rates. $J$ Plankton Res 1981, 3(2):193-201.

62. Zar JH: Biostatistical analysis. Upper Saddle River, New Jersey: Prentice-Hall 1996.

63. Swalwell JE, Petersen TW, Engh van den G: Virtual-core flow cytometry. Cytometry 2009, 75A:960-965

doi:10.1186/1471-2148-10-1

Cite this article as: Koester et al:: Genome size differentiates cooccurring populations of the planktonic diatom Ditylum brightwellii (Bacillariophyta). BMC Evolutionary Biology 2010 10:1

Publish with Bio Med Central and every scientist can read your work free of charge

"BioMed Central will be the most significant development for disseminating the results of biomedical research in our lifetime. " Sir Paul Nurse, Cancer Research UK

Your research papers will be:

- available free of charge to the entire biomedical community

- peer reviewed and published immediately upon acceptance

- cited in PubMed and archived on PubMed Central

- yours - you keep the copyright 